\title{
Twenty-five years of multicultural science education: Looking backward, looking forward ${ }^{1}$
}

\author{
Veinticinco años de educación científica \\ multicultural: mirando al pasado, mirando al \\ futuro
}

\section{Vingt-cinq ans et plus de science de l'éducation multiculturelle: Regard en arrière, regard en avant}

\author{
Eva Krugly-Smolska \\ Queen's University, Canada
}

\begin{abstract}
This paper provides a focused (not comprehensive) review of multicultural science education research in order to determine whether it "has arrived" as a field of inquiry from its meager beginnings over twenty-five years ago. While the answer is yes, given the exponential growth of research in the field, only a qualified yes is allowed given the weaknesses identified: a tendency toward polemical, hypothetical work; over-extrapolation from the data that do exist; and little transference to the classroom - the latter partially due to policy positions and lack of explicit help for teachers in complex contexts. The paper concludes that there is, however, an optimistic future.
\end{abstract}

Key Words: multicultural science as a field of inquiry; minority participation in science; achievement in science; science education.

\section{RESUMEN}

En este artículo se ofrece una revisión (no exhaustiva) de la investigación realizada en torno a la educación científica multicultural. El objetivo es determinar si en los veinticinco años de su presencia académica la educación científica multicultural "se ha configurado" como un campo de investigación. A pesar de que la respuesta es sí, dado el crecimiento exponencial de la investigación en este campo, sólo lo es de manera matizada dadas las debilidades identificadas: 
una tendencia a la polémica; trabajo hipotético; exceso de extrapolación de los datos existentes; y poca transferencia al aula - esta última en parte debido a las posiciones políticas y la falta de ayuda explícita para los/as profesores/as en contextos complejos. Sin embargo, el artículo concluye planteando un futuro optimista.

Descriptores: la ciencia multicultural como campo de investigación; participación de minoría en la ciencia; logros en el dominio de la ciencia; formación científica.

\section{RÉSUMÉ}

Ce papier fournit une revue centrée (non exhaustive) de la recherche en science de l'éducation multiculturelle dans le but de déterminer si elle est "parvenue» comme champ d'enquête depuis sees maigres débuts il y a vingt-cinq ans. Bien que la réponse est oui, étant donné la croissance exponentielle de la recherche dans le domaine, seul un oui qualifié est permis, étant donné les faiblesses identifiées : une tendance à un travail polémique, hypothétique : extrapolation des données qui existent et peu de transfert à la salle de classe - cette dernière lacune est due en partie aux politiques adoptées et à la pénurie d'aide explicite aux enseignants dans des contextes complexes. L'article conclut toutefois que l'avenir est à l'optimisme.

Mots clés: la science multiculturelle comme terrain d'enquête; la participation des minorités à la science; les réalisations dans le domaine de la science; une formation scientifique.

$I^{r}$ N AN ISSUE OF EDUCATIONAL RESEARCHER, Asher stated that "multiculturalism in education is now a given; one may say, indeed, that it has arrived" (2007, p. 65). While she provides evidence for her assertion, she further suggests that the cultural gap between teachers and students is growing in the US context, and then proceeds to interrogate forms of multiculturalism and to provide an alternate vision. The question of whether a similar assertion can be made with respect to science education immediately arises.

Over twenty-five years ago, when I first started working in this field - if it can be called a field - the cultural context of science education (and, for that matter, of science) was with very few exceptions (for example, Holmes, 1977; Maddock, 1981; Wilson, 1981) little acknowledged. Most of my theoretical frameworks and research questions had to be extrapolated from other disciplines and from the general multicultural education literature, which, incidentally, had a different historical trajectory in Canada than in the US (as well as in Europe and elsewhere). Since that time, the literature in the area has proliferated exponentially. My purpose in this article is to provide an overview of that literature, to make explicit my position with respect to that literature, and to determine what we know, as opposed to what we believe, in order to determine whether multicultural science education has arrived. It is not my intention here to go over territory already covered by others, but rather to interrogate it with respect to the overriding question. It is by no means intended as a systematic review of that literature.

By the early- to mid-1990s, the literature had grown to the extent that "taking stock" types of reviews started to appear and evidence of influence on policy was to be found. By 1989, in Ontario, Canada, the Ministry of Education already outlined, in a document regulating secondary education, that multiculturalism: 
should permeate the school's curriculum, policies, teaching methods and materials, courses of study and assessment and testing procedures, as well as the attitudes and expectations of its staff and all their interactions with students, parents and the community. Teachers should be encouraged to develop courses that are consistent with the educational goals of multiculturalism and that reflect fairly and accurately the reality of Canada's multicultural, multiracial society. Principals should ensure that, where relevant, core units exploring the multicultural and multiracial dimensions of issues are incorporated into compulsory subjects. (Ministry of Education, 1989, pp. 9-10)

Science, a compulsory subject in the intermediate years (grades 7-10), therefore fell under this policy - and indeed, there was a section addressing multiculturalism in the concurrent science guidelines. Unfortunately, as I have argued elsewhere (KruglySmolska, 1992), teachers were given very little direction on how to meet those expectations, an issue we will return to below.

If the problem of minority participation ${ }^{2}$ and achievement in science had not been recognized, the seminal article by Oakes (1990), in the US, made it impossible to ignore. It was perhaps the most comprehensive review of its kind that we have seen in the field. Not only did it provide large-scale statistical data, it also investigated possible reasons for the under-representation, with support from a wide range of research studies. The challenge for researchers became clear. Oakes concluded (among other points) that:

we have no grounds for interpreting the relationships among variables that are found, for suggesting what underlying processes and conditions may create group differences, or for speculating about what processes and conditions might be altered to effectively increase participation. (p. 205)

She also suggested that we need further insight on the combined effects of students' multiple status characteristics. What she did not address in her review was the impact of the nature of science itself, other than in the context of stereotyping. That gap was soon filled.

In 1993, a series of articles in Science Education - under then-editor of the Issues and Trends section, Aikenhead (1993) - provoked a flurry of activity. In that issue, Atwater and Riley (1993) provided additional components to the research agenda and identified multicultural science education as an emerging area within science education whose development would require time. Hodson (1993), in another widely cited article, provided a comprehensive examination of various aspects of multicultural science education and so presented a further rationale, if Oakes' data were not convincing enough. Interestingly, many of the important aspects of his argument were not necessarily taken up; the flurry of activity was triggered by his discussion of multicultural science. Epistemological debates flourished (for example, Good, 1995; Loving 1995; Ogawa, 1995; Stanley \& Brickhouse, 1994; Williams, 1994) and continue to this day (as in Irzik \& Irzik, 2002; Krugly-Smolska, 2004). Nola and Irzik 
(2006) concluded that postmodernism and multiculturalism have nothing to offer as a theory of knowledge and as a theory of science. Furthermore, they concluded that as a pedagogical theory, these have disastrous consequences and should be left out of the classroom (p. 462). Such a conclusion is bound to re-energize the debate, but I do not wish to engage in it here.

Instead, I wish to raise a more immediate concern with some of Hodson's assertions. Hodson tells us that it is often children of ethnic minorities who fail to achieve affective goals of self-image and self-worth and "as a consequence [my emphasis] underachieve in secondary school science and are underrepresented in science courses at the tertiary level" (p. 686). He further states that science curriculum does little to raise this self-esteem, and "is seen by many as irrelevant to their experiences, needs, interests and aspirations. Among the several causal [my emphasis] factors are" such things as the curriculum's Western orientation, racist and sexist materials, inappropriate methods given minorities' cultural traditions, and the image of the scientist (p. 687). The concern is that no evidence is provided for the causal link in either case. That these factors are no doubt important (and I believe they are, in my theoretical understanding of multicultural science education) is not so much the issue, as that they were, at this stage, no more than hypothesized links. In fact, Oakes (1990) told us that very little attention had been given to affective factors and the relationship to achievement and participation in science and mathematics by minorities, that "most analyses have been correlational, many based on rather small samples," and that "conclusions about the influence of most affective factors remain tentative" (p. 171). ${ }^{3}$

Hodson is not alone in his zealousness to make the case. Much of the early writing in multicultural science education is of the persuasive essay, discursive analysis type, if not outright polemical. At a time when most viewed science and science education as acultural, this was to be understood. The danger now - if we continue to pursue such activity without research support - is that if we do not test our hypotheses, we may end up taking or suggesting actions in classrooms which may have unintended results (see, for example, Lustig, 1997; Ulichny, 1996). In intermingling disciplinary perspectives and methodologies, we must be careful to regard the rules of evidence and forms of validation (Labaree, 1998). In fact, contrary to expectations based on my theoretical framework (Krugly-Smolska, 1995), I found that minority students in three secondary classrooms were actually outperforming so-called majority students. It must be remembered, however, that many of these students had studied science elsewhere, and so may have had important prior experiences with science (see, as comparison, Cogan, Wang, \& Schmidt, 2001). A cooperative approach, attentiveness, and a quick learning of the cultural expectations of the classroom probably also contributed. The complex context of the science learning must always be kept in mind, including students' previous experiences. ${ }^{4}$

Pomeroy (1994), in her mapping of the field and research agendas, avoids the common trap of assuming relationships by examining them as beliefs that lead to particular goals and actions. In the process, she describes the rationales for the beliefs and identifies research on implementation, where available. One observation from this analysis suggests that encouraging students to like science (affective goals) may 
not be as important as teachers having high expectations and believing that all students can learn science.

Perhaps the most influential article in the field is Aikenhead's (1996) treatment of science learning as cultural acquisition and border crossing into the subculture of science. It was comprehensive and substantively based on empirical evidence. In discussing some of that evidence, he informed us that most culture-related research was found in non-Western settings. It is evident that some extrapolation was necessary on his part in addressing his primary (in this case, at least) concern of Western students in industrialized countries. Interestingly, he did not use the term "multicultural" in that article. He did acknowledge, however, that "in addition to the subculture of science and school science, students must deal with, and participate in, an array of other important subcultures in their lives" (p.14). This view is consistent with my own position (Krugly-Smolska, 1996) that every science classroom is multicultural.

Should the important role of culture in science learning lead us to change the name of the field to culture/cultural studies in science education (Krugly-Smolska, 1999)? I think not. By keeping the term "multicultural," we build on important existent realities, in line with curriculum and policy initiatives, but also expand the field to other theoretical explorations in addition to culture. These may include power relations, economic inequalities, anti-racism, post-colonialism, and so on. But it is important to continue to use the term in its widest sense and not as a euphemism for anti-racist education, as sometimes has been the case in the US. For me, multicultural science education and research involve the following contexts: science education occurring in non-Western cultural context, science education in a Western context but with populations of predominantly non-Western origin (for example, aboriginal populations), and science education in a Western context but with populations of varied cultural origin, both Western and non-Western. This latter group may contain minorities with different status - such as immigrants or involuntary minorities, using Ogbu's (1987) terminology - and in some classrooms, they may actually be a majority in terms of numbers.

Insights gained and successful strategies from one context may be tested and applied in the others, and so the impact could be exponential. For example, Baker and Taylor (1995), in their review of a small number of studies in non-Western contexts, emphasized the importance of language (mother tongue) in learning science and its relationship to concept development, as well as resistance of traditional understandings to conceptual change. These same issues are found in Tobin and McRobbie's (1996) study with Chinese-Australians and Lee, Fradd, and Sutman's (1995) research with culturally and linguistically diverse students in the US. In fact, Aikenhead (1996) extrapolates such findings and maintains that the same issues apply to all students (see, as comparison, Hogan \& Corey, 2001). Many further such examples could be provided, as can further support for Baker and Taylor's conclusions. Instead, I would like to fast-forward a decade, to the present.

Given the discussion up to this point and the literature reviewed (including the literature not reviewed and that included in previous reviews), one would assume that the field is quite well established. That assumption is put into question by two recent 
books. Aikenhead (2006) states that "[b]ecause culture studies in science education is an emerging research field, its findings are limited at this time" (p.109). But we must be careful not to take this statement out of context. His purpose is to encourage a humanistic science education that is evidence-based. My interpretation of his comment is that, in the area of culture studies, the links between certain practices and student success, participation in science, or attaining scientific literacy have not been made adequately.

Let me provide just one example (not Aikenhead's). Parsons (2000) describes the teaching of the water cycle in elementary science that she suggests reflects an AfricanAmerican cultural frame of reference. This is accomplished through a dance and representation of raindrops falling, moving in the oceans, and then rising again as in evaporation. Parsons claims that this activity "displayed the Black culture values of harmony, verve, affect and movement" (p. 215). Let us assume that she is correct (although another explanation of the activity could be that it addresses Gardner's multiple intelligences). What we do not know is whether this activity is effective in having students learn and understand the water cycle beyond "making learning fun" (laudable though that may be). There are a myriad of these suggested activities and small case study examples, but we have no way of knowing whether they are transferable and accomplish what is claimed.

Lee and Luykx's (2006) new synthesis of research findings is in many ways an updated version of Oakes' (1990) important contribution. In it, also, there is recognition of science education and diversity as a relatively new field of inquiry (p. ix). Many of the same inadequacies in the research identified by Oakes are also identified here (for example, p. 11). Among the results presented (mostly from the US), there is a suggestion that "it is the economic and educational marginalization associated with racial/ethnic minority status rather than students' racial/ethnic or cultural background per se, that negatively affects minority students' science achievement" (p. 139). Such a finding does not contradict cultural explanations of success in science. The importance of class culture and the cultural capital associated with it, whether valued or not, is an important factor in such explanations.

The comprehensive nature and the number of studies cited in Lee and Luykx's review seem to belie the emerging nature of the field. On the other hand they conclude:

The relationship between students' science outcomes (particularly achievement data) and educational processes or mechanisms is tenuous in most studies. Studies focusing on educational processes or mechanisms often do not report student outcome data, and studies linking student outcomes to causal mechanisms or factors are even fewer. Studies reporting on the impact of intervention programs on achievement gaps among racial/ethnic, cultural, linguistic and socioeconomic groups are scarce. (p. 148)

It seems, then, that there has been a great deal of research in the area, but the nature of the research has not been adequate to ensure that our strategies are effective. On the other hand, Lee and Luykx do report that there has been some narrowing of the 
achievement gaps in the US. Given this situation, I am led to conclude that multicultural science education research has arrived, and the directions for future research seem to be quite clear - as identified by many of the authors cited here - including a need for meta-analysis of small qualitative studies, where much of the work in this field has taken place.

However, I am not fully convinced that we can say that multicultural science education has, indeed, arrived. One of the reasons, I suggest, is the documented difficulty (see, for example, Atwater, Crockett, \& Freeman, 2001; Brand \& Glasson, 2004; Fraser-Abder, 2001; Sweeney, 2001) of getting science teachers to see the need for this approach to science teaching. In order for any kind of further movement in this area, teachers will need to see this not as an added requirement, but as an integrated aspect of their recognition that no two children are alike, and an important component in reaching their goal of science education for all. Unfortunately, even when they are convinced of this, there continues to be little help for them in their implementation strategies. Heikkinen and Eide (1998) reviewed teacher resource manuals for twenty-one of the most popular middle school science textbooks in the US and found that:

The multicultural content was most often found in very small amounts, usually two to four sentences that covered approximately one tenth of a page, inserted at the rate of one per chapter and/or unit. The purpose for the inclusion of the material was not identified and only in rare cases were suggestions given on how the teacher could use or structure the information to support the learning objectives as indicated in the teachers' manuals. (p. 193)

Even more disconcerting, perhaps, are recent policy shifts, which seem to see science education as primarily meeting competitive economic goals in a global market. At the beginning of this article, I referred to policy in Ontario, which encouraged multicultural education. The science documents also referred to multiculturalism, immigrant students, and sensitive issues. The 1999 Ontario guidelines no longer had such explicit messages. Instead, there was a brief mention at the end of the document of English as a second language and English literacy development (ESL/ESD), which acknowledges the linguistic challenges of science for all students and that teachers should respond to the special needs of ESL students. Specifically, multicultural content is represented by three expectations (outcomes) in the whole of the grade $9 / 10$ program, which state that students should be able to:

- relate the beliefs of various cultures concerning celestial objects to aspects of their civilization (e.g. aboriginal beliefs, Greek mythology, Mayan civilization (p. 21).

- describe ways in which the relationships between living organisms and their ecosystems are viewed by other cultures (e.g. First Nations) (p. 26, p. 35). 
- compare various cultural (e.g. First Nations) and historical views on the origins and interpretations of weather (p. 30).

These are the equivalent of the early stages of incorporating multiculturalism in the classroom that incorporated the "dine, dress, dance" components and in many cases were treated superficially. In Ontario, we had moved a great deal beyond that, and so it seems, where we had taken two steps forward, we have now taken one step back. These guidelines are soon to be revised under a new government, and I am optimistic that we will move forward again.

The three expectations that were identified above appeared in the "relating science to technology, society and the environment" overall goal of the program (the other two being "to understand basic concepts" and "to develop the skills, strategies and habits of mind required for scientific inquiry"). It seems, therefore, that under the current situation we would need to heed the example of Sweeney (2001), who suggests that multicultural science education and science, technology, and society (STS) education make a good match. Such an integrated approach may also make sense for those who consider important science education's role in promoting active citizenship (see, for example, Wildemeersch, Stroobants, \& Bron, 2005). You do what you can within the context in which you work.

This may seem to be a pessimistic view as we look forward to the next twenty-five years of multicultural science education. I do not intend it to be. There are many more researchers and teachers working in the area than there were. A new research journal addresses sociocultural perspectives specifically (Tobin, 2006), and few still consider science or science education acultural. There are even collections for an educated general public that attest to this (as in Eisen \& Laderman, 2007).

We have come a long way, but we have a long way to go. It is important that we continue to promote the message loudly and clearly. In countries where a multicultural science education has not yet been addressed or even recognized, UNESCO's (2007) science committee's recent focus on science education and protection of cultural diversity may be a useful partner to engage. Scientific knowledge has great value as cultural capital; until access to it is equally available to all who seek it, true equity in our societies will not be reached. I look forward, optimistically, to continued endeavours to reach that goal. ${ }^{5}$

\section{Notes}

1. An earlier version of this paper was presented as a keynote address to the European Science Education Research Association, Malmö, Sweden, August 2007.

2. Who the minority populations underrepresented are varies from country to country. In the US, research focuses on African-Americans and Hispanics. In Canada, the most underrepresented are Aboriginal students.

3. Work by Ainley and Ainley (2011) addresses this and provides recent data in this 
tradition.

4. Taber (2012) suggests that this is still not being adequately addressed, while Ma (2012) makes an attempt to do so.

5. Lee and Buxton (2010) provide a more recent comprehensive synthesis of the relevant research (mostly from the US). However, Feinstein (2011) suggests there is some lack of quality discrimination in the studies included, as well as weaknesses in the theoretical arguments.

\section{References}

Aikenhead, G. (1993). Foreword: Multicultural issues and perspectives in science education. Science Education, 77(6), 659-660.

Aikenhead, G. (2006). Science education for everyday life - Evidence-based practice. New York, NY: Teachers College Press.

Ainley, M., \& Ainley, J. (2011). A cultural perspective on the structure of student interest in science. International Journal of Science Education, 33(1), 51-71.

Asher, N. (2007). Made in the (multicultural) USA: Unpacking tensions of race, culture, gender, and sexuality in education. Educational Researcher, 36(2), 65-73.

Atwater, M. M., Crockett, D., \& Freeman, T. (2001). Science teachers' journeys in multiculturalism: A continuing saga. In S. R. Steinberg (Ed.), Multi/Intercultural Conversations (pp. 313-339). New York, NY: Peter Lang.

Atwater, M. M., \& Riley, J. P. (1993). Multicultural science education: Perspectives, definitions, and research agenda. Science Education, 77(6), 661-668.

Baker, D., \& Taylor, P. C. S. (1995). The effect of culture on the learning of science in nonWestern countries: The results of an integrated research review. International Journal of Science Education, 17(6), 695-704.

Brand, B. R., \& Glasson, G. E. (2004). Crossing cultural borders into science teaching: Early life experiences, racial and ethnic identities, and beliefs about diversity. Journal of Research in Science Teaching, 41(2), 119-141.

Cogan, L. S., Wang, H. A., \& Schmidt, W. H. (2001). Culturally specific patterns in the conceptualization of the school science curriculum: Insights from TIMSS. Studies in Science Education, 36, 105-134.

Eide, K. Y., \& Heikkinen, M. W. (1998). The inclusion of multicultural material in middle school science teachers' resource materials. Science Education, 82, 181-195.

Eisen, A., \& Laderman, G. (Eds.) (2007). Science, religion, and society - An encyclopedia of history, culture and controversy. Armonk, NY: M. E. Sharpe.

Feinstein, N. (2011). Review of Lee, O., \& Buxton, C. A. (2010), Diversity and equity in science education: Research, policy and practice. Science Education, 95(3), 571-573.

Fraser-Abder, P. (2001). Preparing science teachers for culturally diverse classrooms. Journal of Science Teacher Education, 12(2), 123-131.

Good, R. (1995). Comments on multicultural science education. Science Education, 79(3), 335-336.

Hodson, D. (1993). In search of a rationale for multicultural science education. Science 
Education, 77(6), 685-711.

Hogan, K., \& Corey, C. (2001). Viewing classrooms as cultural contexts for fostering scientific literacy. Anthropology \& Education Quarterly, 32(3), 214-243.

Holmes, B. (1977). Science education: Cultural borrowing and comparative research. Studies in Science Education, 4, 83-110.

Irzik, G., \& Irzik, S. (2002). Which multiculturalism? Science \& Education, 11, 393-403.

Krugly-Smolska, E. (1992). Mainstreaming multicultural education: The role of science education. Canadian Ethnic Studies, XXIV(3), 137-144.

Krugly-Smolska, E. (1995). Cultural influences in science education. International Journal of Science Education, 17(1), 45-58.

Krugly-Smolska, E. (1996). Scientific culture, multiculturalism and the science classroom. Science \& Education, 5, 21-29.

Krugly-Smolska, E. (1999). Research on multiculturalism applied to students' learning school science: Some theoretical issues. Paper presented at NARST pre-conference, Boston, MA, March. http://www.ouhk.edu.hk/ rcwww/misc/krugly.htm

Krugly-Smolska, E. (2004). Let's stop talking about Western science. Canadian Journal of Science, Mathematics and Technology Education, 4(2), 419-422.

Labaree, D. F. (1998). Educational researchers: Living with a lesser form of knowledge. Educational Researcher, 27(8), 4-12.

Lee, O., \& Buxton, C. A. (2010). Diversity and Equity in Science Education: Research, Policy and Practice. New York, NY: Teachers College Press.

Lee, O., Fradd, S. H., \& Sutman, F. X. (1995). Scientific knowledge and cognitive strategy use among culturally and linguistically diverse students. Journal of Research in Science Teaching, 32(8), 797-816.

Lee, O., \& Luykx, A. (2006). Science education and student diversity - Synthesis and research agenda. New York, NY: Cambridge University Press.

Loving, C. C. (1995). Comment on "Multiculturalism, universalism and science education." Science Education, 79(3), 341-348.

Lustig, D. F. (1997). Of Kwanza, Cinco de Mayo, and whispering: The need for intercultural education. Anthropology \& Education Quarterly, 28(4), 574-592.

Ma, H. (2012). The images of science through cultural lenses - A Chinese study on the nature of science. Rotterdam, Netherlands: Sense Publishers.

Maddock, N. M. (1981). Science education: An anthropological viewpoint. Studies in Science Education, 8, 1-26.

Nola, R., \& Irzik, G. (2006). Philosophy, science, education and culture. Dordrecht, Netherlands: Springer.

Oakes, J. (1990). Opportunities, achievement, and choice: Women and minority students in science and mathematics. Review of Research in Education, 16, 153-222.

Ogawa, M. (1995). Science education in a multiscience perspective. Science Education, 79(5), 583-593.

Ogbu, J. U. (1987). Variability in minority student performance: A problem in search of an explanation. Anthropology \& Education Quarterly, 18(4), 312-334.

Ontario Ministry of Education (1989). Ontario Schools: intermediate and senior divisions. Toronto, Canada: Ontario Government Printers. 
Ontario Ministry of Education and Training (1999). The Ontario curriculum grades 9 and 10 - Science. Toronto, Canada: Ontario Government Printers.

Parsons, E. C. (2000). Culturalizing science instruction: What is it? What does it look like and why do we need it? Journal of Science Teacher Education, 11(3), 207-219.

Pomeroy, D. (1994). Science education and cultural diversity: Mapping the field. Studies in Science Education, 24, 49-73.

Stanley, W. B., \& Brickhouse, N. W. (1994). Multiculturalism, universalism, and science education. Science Education, 78(4), 387-398.

Sweeney, A. E. (2001). Incorporating multicultural and science-technology-society issues into science teacher education courses: Successes, challenges and possibilities. Journal of Science Teacher Education, 12, 1-28.

Taber, K. S. (2012). The cultures of science education across the world. Studies of Science Education, 48(2), 229-235.

Tobin, K. (2006). Editorial: Toward a cultural turn in science education. Cultural Studies in Science Education, 1, 7-10.

Tobin, K., \& McRobbie, C. J. (1996). Significance of limited English proficiency and cultural capital to the performance in science of Chinese-Australians. Journal of Research in Science Teaching, 33(3), 265-282.

Ulichny, P. (1996). Cultures in conflict. Anthropology \& Education Quarterly, 27(3), 331-364.

UNESCO (2007). Draft medium-term strategy 34 C/4 (2008-2013). Paris, France: UNESCO.

Wildemeersch, D., Stroobants, V., \& Bron, M. (Eds.) (2005). Active citizenship and multiple identities in Europe. Frankfurt am Main, Germany: Peter Lang.

Williams, H. (1994). A critique of Hodson's "In search of a rationale for science education." Science Education, 78(5), 515-519.

Wilson, B. W. (1981). The cultural contexts of science and mathematics education: Preparation of a bibliographic guide. Studies in Science Education, 8, 27-44. 